\title{
LEARNING TRAJECTORIES BASED INQUIRY UNTUK MEMBANGUN MATHEMATICAL KNOWLEDGE FOR TEACHING GURU ANAK USIA DINI
}

\author{
Mery Noviyanti \\ Fakultas Keguruan dan Ilmu Pendidikan, Universitas Terbuka \\ meryn@ecampus.ut.ac.id
}

Penerimaan : 17 Januari 2018

Diterima: 30 Desember 2018

\begin{abstract}
ABSTRAK
Guru mempunyai peran penting dalam meningkatkan kemampuan matematika anak. Oleh karena itu, Mathematical Knowledge for Teaching (MKT) harus dibangun dan ditingkatkan agar dapat melakukan kegiatan pengembangan dengan baik. Untuk meningkatkan kualitasnya, para guru diharapkan terlibat dalam pengembangan profesional atau Professional Development Program (PDP). PDP merupakan sarana untuk menigkatkan dan mempertahankan pengetahuan dan keterampilan yang berkaitan dengan kehidupan profesional guru. Dalam pengembangan program tersebut, diperlukan sebuah model pembelajaran sebagai pedoman pelaksanaannya. Model tersebut diharapkan dapat memancing logika dan pengetahuan guru dalam mengajar matematika. Learning Trajectories Based Inquiry (LTBI) merupakan lintasan belajar dengan menekankan kepada proses mencari dan menemukan. Dalam hal ini, pengetahuan dibangun melalui proses pencarian, serta proses berpikir kritis dan analitis untuk merumuskan kesimpulan. Makalah ini akan membahas apa yang dimaksud dengan Learning Trajectories Based Inquiry (LTBI), bagaimana merancang model LTBI dalam pelaksanaan Professional Development Program (PDP). Serta bagaimana pelaksanaan PDP dengan model LTBI dapat membangun MKT.
\end{abstract}

Kata Kunci: Learning Trajectories Based Inquiry, Mathematical Knowledge for Teaching, Professional Development Program

\section{PENDAHULUAN}

Pendidikan anak usia dini (PAUD) saat ini menjadi perhatian para ilmuwan di dunia. Salah satunya tertuju kepada matematika untuk anak usia dini (AUD). Gardner (2007) menyatakan kecerdasan logika matematika merupakan salah satu dari sembilan jenis potensi kecerdasan yang dimiliki anak. Matematika AUD sangat penting bagi perkembangannya dimasa yang akan datang. Anak-anak yang melakukan kegiatan pengembangan matematika dari 0 sampai 6 tahun, akan tampil lebih baik pada tugas-tugas akademik seperti membaca, menulis dan matematika. Selain itu, mereka menjadi lebih mampu dari interaksi sosial dengan anak-anak lain dan orang dewasa (lino, 2016). Sedangkan Wilson (2012) yang mengemukakan terdapat pengaruh yang signifikan pada kemampuan anak diusia 54 bulan terhadap prestasi matematika anak 15 tahun. 
Guru mempunyai peran penting dalam membangun kemampuan matematika anak. Pengetahuan guru mempengaruhi prestasi matematika siswa mereka (Hill, 2005). Seorang guru yang baik sudah seharusnya dapat menguasai konten (materi subjek) dan ilmu mengajar (pedagogi) (Leong, 2015). (NCTM, 2000) menambahkan bahwa pengetahuan pedagogis dan pengetahuan konten matematika perlu dikuasai oleh guru matematika yang ingin menjadi guru professional. Hal tersebut terkait dengan Mathematical Knowledge for Teaching (MKT). menyatakan bahwa guru matematika perlu meningkatkan MKT. MKT terdiri dari dua bagian yaitu Pedagogical Content Knowledge (PCK) dan Subject Matter Knowledge (SMK) (Ball\&Bass, 2008; Hill, 2004). Guru harus mempunyai kemampuan yang cukup untuk menjadikan belajar matematika yang berkesan dan menyenangkan untuk anak usia dini.

Berkaitan dengan guru AUD, konsep bilangan merupakan materi yang dianggap sulit untuk diperkenalkan kepada anak. Sedangkan menurut Noviyanti (2017) guru mempunyai kesulitan mengahadapi kemampuan anak yang berbeda pada saaat mengajar konsep bilangan. Para guru harus mampu menemukan metode atau strategi apa yang cocok untuk melakukan kegiatan pengembangan konsep bilangan di sekolahnya.

Untuk menungkatkan kualitasnya, para guru diharapkan terlibat dalam pengembangan profesional atau Professional Development Program (PDP). PDP merupakan sarana untuk menigkatkan dan mempertahankan pengetahuan dan keterampilan yang berkaitan dengan kehidupan profesional guru. Untuk menjadi guru yang berkualifikasi tinggi, maka pengembangan profesional guru yang pada peningkatan pengalaman dan prestasi belajar siswa (Desimone, 2009).

Dalam pengembangan PDP, diperlukan sebuah model pembelajaran sebagai pedoman pelaksanaannya. Model tersebut diharapkan dapat memancing logika dan pengetahuan guru dalam mengajar matematika. Wilson (2012) mengemukakan bahwa Learning Trajectories LTs pada pembelajaran mendukung penyempurnaan dari Mathematical Knowledge for Teaching (MKT) guru.

LTs adalah lintasan belajar terdiri dari langkah-langkah yang signifikan dalam pembelajaran topik tertentu; setiap langkah baru dalam jalur pembelajaran didasarkan pada langkah-langkah sebelumnya (Kuhne,2015). Dalam hal ini, Pendididik pada saat merancang lintasan harus mempertimbangkan tugas-tugas yang digunakan dan tujuan pembelajaran.

Disisi lain, untuk membangun MKT pendidik perlu memberikan kesempatan pada peserta didik untuk menguji dan menafsirkan problem secara sistematika yang memberikan konklusi berdasarkan pembuktian. Hal tersebut berkaitan dengan Inquiri 
Untuk itu perpaduan LTS dan Inquiry diharapkan mampu membangun MKT tersebut. Perpaduan model tersebut dinamakan Learning Trajectories Based Inquiry (LTBI) . LTBI merupakan lintasan beajar dengan menekankan kepada proses mencari dan menemukan. Pengetahuan dibangun melalui proses pencarian, serta proses berpikir kritis dan analitis untuk merumuskan kesimpulan.

Dalam makalah ini akan diperoleh gambaran mengenai Learning Trajectories Based Inquiry (LTBI); Menghasilkan rancangan model Learning Trajectories Based Inquiry (LTBI) dalam pelaksanaan Professional Development Program (PDP); serta Memperoleh gambaran bagaimana pelaksanaan Professional Development Program (PDP) dengan model LTBI dapat membangun Mathematical Knowledge for Teaching (MKT).

\section{LEARNING TRAJECTORIES}

Martin Simon pertama kali menggunakan istilah 'learning trajectory'(LTs) pada tahun 1995. Dalam penggunaan istilah tersebut, Simon menamakan 'hypothetical learning trajectory' untuk menggambarkan bahwa jalan yang ditempuh oleh pembelajaran dapat bervariasi berdasarkan pada pengalaman dan konteks siswa. Dengan demikian, lintasan pembelajaran merupakan predikasi jalan dimana pembelajaran dapat dilanjutkan yang diinformasikan oleh penelitian, pemahaman tentang matematika, dan pengalaman. LTs telah didefinisikan sebagai deskripsi pemikiran dan rute/ lintasan mengenai dugaan peserta didik dengan serangkaian tugas instruksional yang dirancang untuk menimbulkan proses-proses mental atau tindakan hipotesis berdasarkan perkembangan anak (Clements, 2004).

Clements (2004) menyataan bahwa LTs mempunyai tiga bagian penting yakni: tujuan pembelajaran matematika yang ingin dicapai, lintasan perkembangan yang akan dikembangkan oleh peserta didik dalam mencapai tujuan pembelajaran, dan seperangkat kegiatan pembelajaran ataupun tugas-tugas. Confrey (2009) mendefinisikan LTs sebagai jaringan yang membangun konstruks peserta didik (yaitu, kegiatan, tugas, alat, bentuk interaksi dan metode evaluasi), untuk pindah dari ide informal, melalui perbaikan berturut representasi, artikulasi, dan refleksi, terhadap konsep yang semakin kompleks dari waktu ke waktu.

Dalam perkembanganya, LTs penting untuk 1) membangun gambaran yang jelas tentang gagasan besar tentang matematika dan 2) meletakkan jalan untuk belajar membantu anak mengembangkan gagasan besar tersebut (Clements, 2009). Clements menegaskan bahwa LTs membantu guru untuk menafsirkan apa yang dipikirkan dan dilakukan siswa 
secara matematis. Hal ini membantu guru mengenai langkah selanjutnya dalam melakukan kegiatan pengembangan.

\section{INQUIRY}

Model atau pendekatan pembelajaran inkuiri merupakan salah satu bentuk pendekatan pembelajaran yang berpusat pada peserta didik (student centered approach). Ciri utama yang dimiliki oleh pendekatan inkuiri yaitu menekankan kepada aktivitas peserta didik secara maksimal untuk mencari dan menemukan (menempatkan peserta didik sebagai subjek belajar) (Sanjaya, 2009).

Pengertian Model pembelajaran inquiry diartikan sebagai proses pembelajaran yang didasarkan pada pencarian dan penemuan melalui proses berpikir secara sistematis. Sasaran utama penerapan model ini adalah sebagai berikut.

1) Keterlibatan peserta didik secara maksimal dalam proses kegiatan belajar. Kegiatan belajar di sini adalah kegiatan mental intelektual dan sosial emosional.

2) Keterarahan kegiatan secara logis dan sistematis pada tujuan pengajaran.

3) Mengembangkan sikap percaya pada diri sendiri (self-belief) pada diri peserta didik tentang apa yang ditemukan dalam proses inkuiri.

Sedangkan fase model inquiri adalah sebagai berikut (Sanjaya, 2009)

Tabel 1. Fase model Inkuiri

\begin{tabular}{llrl}
\hline No & \multicolumn{1}{c}{ Fase } & \multicolumn{1}{c}{ Prilaku Pendidik } \\
\hline $\mathbf{1}$ & $\begin{array}{l}\text { Menyajikan pertanyaan } \\
\text { masalah }\end{array}$ & atau & $\begin{array}{l}\text { Pendidik membimbing siswa mengidentifikasikan } \\
\text { masalah dan masalah dituliskan di papan tulis. } \\
\text { Pendidik membagi siswa dalam kelompok }\end{array}$ \\
\hline $\mathbf{2}$ & Membuat hipotesis & $\begin{array}{l}\text { Pendidik memberikan kesempatan pada siswa } \\
\text { untuk curah pendapat dalam bentuk hipotesis. } \\
\text { Pendidik membimbing siswa dalam menentukan } \\
\text { hipotesis yang relevan dengan permasalahan dan } \\
\text { memprioritaskan hipotesis mana yang menjadi } \\
\text { prioritas pendidikan }\end{array}$ \\
& & $\begin{array}{l}\text { Pendidik memberikan kesempatan kepada siswa } \\
\text { untuk menentukan langkah-langkah yang sesuai } \\
\text { dengan hipotesis yang dilakukan }\end{array}$ \\
\hline $\mathbf{3}$ & Merancang percobaan & $\begin{array}{l}\text { Pendidik membimbing siswa mendapatkan } \\
\text { informasi melalui percobaan }\end{array}$ \\
\hline $\mathbf{4}$ & Melakukan percobaan & untuk \\
memperoleh informasi & Megumpulkan dan menganalisis & $\begin{array}{l}\text { Pendidik memberikan kesempatan kepada tiap } \\
\text { kelompok untuk menyampaikan hasil pengolahan } \\
\text { data yang terkumpul }\end{array}$ \\
\hline $\mathbf{6}$ & Membuat kesimpulan & $\begin{array}{l}\text { Pendidik membimbing siswa dalam membuat } \\
\text { kesimpulan }\end{array}$ \\
\hline
\end{tabular}


Gulo (2004) mengemukakan kondisi-kondisi umum yang merupakan syarat bagi timbulnya kegiatan inkuiri bagi peserta didik. Kondisi tersebut antara lain sebagai berikut.

1) Aspek sosial di dalam kelas dan suasana terbuka yang mengundang peserta didik berdiskusi. Hal ini menuntut adanya suasana bebas (permisif) di dalam kelas, di mana setiap peserta didik tidak merasakan adanya tekanan atau hambatan untuk mengemukakan pendapatnya. Adanya rasa takut, atau rasa rendah diri, atau rasa malu dan sebaginya, baik terhadap teman, peserta didik, maupun terhadap Pendidik adalah faktor-faktor yang menghambat terciptanya suasana bebas di kelas. Kebebasan berbicara dan penghargaan terhadap pendapat yang berbeda sekalipun pendapat itu tidak relevan, perlu selalu dipelihara dalam batas-batas disiplin yang ada.

2) Inkuiri berfokus pada hipotesis. Peserta didik perlu menyadari bahwa pada dasarnya semua pengetahuan bersifat tentatif. Tidak ada kebenaran yang bersifat mutlak. Kebenarannya selalu bersifat sementara. Sikap terhadap pengetahuan yang demikian perlu dikembangkan. Dengan demikian, maka penyelesaian hipotesis merupakan fokus strategi inkuiri. Apabila pengetahuan dipandang sebagai hipotesis, maka kegiatan belajar berkisar sekitar pengujian hipotesis dengan pengajuan berbagai informasi yang relevan. Sehubungan adanya berbagai sudut pandang yang berbeda di antara peserta didik, maka sedapat mungkin dimungkinkan adanya variasi penyelesaian masalah sehingga inkuiri bersifat open ended. Inkuiri bersifat open ended jika ada berbagai kesimpulan yang berbeda dari peserta didik masing-masing dengan argumen yang benar sebagai hasil proses inkuiri.

3) Penggunaan fakta sebagai evidensi. Di dalam kelas dibicarakan validitas dan reliabiltas tentang fakta sebagaimana dituntut dalam pengujian hipotesis pada umumnya

\section{MATHEMATICAL KNOWLEDGE FOR TEACHING}

Pada tahun 1986, Shulman memetakan pengetahuan guru berdasarkan tiga kategori pengetahuan konten: (a) subject matter content knowledge, (b) pedagogical content knowledge, dan (c) curricular knowledge. Sejalan dengan perkembangan pendidikan matematika, Ball mengembangkan teori pengetahuan professional yang digunakan oleh guru melakukan kegiatan pengembangan. Teorinya mencakup gagasan Shulman tentang pedagogical content knowledge (PCK) dan menambahkan kategori kedua yaitu Subject Matter Knowledge (SMK). Selanjutnya, teori tersebut dinamaka Mathematical Knowledge for Teaching (MKT). 
Subject Matter Knowledge (SMK) berkaitan dengan tingkat pengetahuan guru dalam menguasai matematika terutama materi mata yang akan diajarkan. SMK diuraikan menjadi beberapa komponen, yaitu Common Content Knowledge (CCK) dan Specialized Content Knowledge (SCK). Common Content Knowledge (CCK) merupakan pengetahuan matematis yang sangat dasar dan sifatnya sangat umum. Pengetahuan ini dimiliki biasa dimiliki oleh guru mata pelajaran apapun. Sedangkan Specialized content knowledge (SCK) merupakan pengetahuan khusus yang hanya dimiliki oleh guru matematika. Bagian ini mengacu kepada pengetahuan dan kemampuan spesifik yang terbentuk ketika melakukan kegiatan pengembangan. Pada penelitian ini, akan dianalisis bagaimana pengetahuan guru tentang Matematika AUD.

Pedagogical Knowledge for Teaching (PCK) secara umum mengacu pada kemampuan mengajar matematika secara efektif (Ball, 2008). PCK merupakan pengetahuan tentang pedagogi atau etika dan pengetahuan tentang konten atau hal lainnya yang berkaitan dengan materi yang diajarkan, dalam hal ini konten matematika. Ball (2008) terdapat tiga bagian dari PCK yaitu: Knowledge of Content and Students (KCS), Knowledge of content and teaching (KCT), dan Knowledge of Curriculum (KC). Ball menjelaskan bahwa KCS merupakan gabungan dari pengetahuan tentang siswa dan pengetahuan tentang matematika. Selain itu, KCS juga merupakan kemampuan dalam memprediksi dan menganalisis proses berpikir siswa. Ball menambahkan kemampuan konsepsi dan miskonseppsi umum pada siswa tentang konten tertentu dalam matematika termasuk kedalam komponen KCS.. Komponen KCT memerlukan sebuah interaksi antara pemahaman matematika yang spesifik dan sebuah pemahaman isu pedagogis yang mempengaruhi pemebelajaran siswa (Ball dkk., 2008, hlm. 400). Sedangkan berkaitan dengan KC, Tipe pengetahuan ini mengacu pada pengetahuan guru tentang kurikulum yang merupakan dasar penting bagi seorang guru untuk memahami tugas dan perannya. KC ini mencerminkan seberapa jauh guru mengenal perangkat kurikulum yang menjadi pedoman dalam kegiatan pengembangan.

\section{RANCANGAN MODEL LEARNING TRAJECTORIES BASED INQUIRY DALAM PELAKSANAAN PROFESSIONAL DEVELOPMENT PROGRAM}

Para guru di Indonesia menyadari bahwa jabatan guru adalah suatu profesi yang terhormat dan mulia. Untuk menungkatkan kualitasnya, para guru diharapkan terlibat dalam pengembangan profesional. Professional Development Program (PDP) merupakan sarana untuk menigkatkan dan mempertahankan pengetahuan dan keterampilan yang berkaitan dengan kehidupan profesional mereka. 
Selain penguasaan kompetensi profesional, seorang guru profesional juga diharuskan menguasai kompetensi pedagogis. Guru selalu mencari strategi yang paling efektif dalam mengajar matematika dan mencari strategi keragaman dan pendekatan pembelajaran. Ini juga merupakan ciri khas seorang guru profesional.

Dalam penelitian ini dikembangkan program PDP dengan model LTBI. Model ini pernah diterapkan oleh Deakun (2017) dengan tujuan memperdalam pemahaman tentang konsep matematika AUD dan bagaimana anak-anak mengembangkan pemahaman matematis, kebutuhan akan pemecahan masalah dan kegiatan yang sesuai dengan perkembangan dan perkembangan yang kita ikuti, berpartisipasi dalam diskusi kritis, berpartisipasi dalam sesi co-teaching and planning, berkolaborasi dengan sesama rekan kerja, memperkuat pemahaman dan keahlian dalam menciptakan dokumentasi pedagogis sebagai sarana untuk melacak, memantau dan mewakili pembelajaran siswa. Berikut ini adalah rancangan PDP dengan Model LTBI.

\section{Tabel 2. Model Learning Trajectories Based Inqury}

\begin{tabular}{ll}
\hline \multicolumn{1}{c}{ Kegiatan } & \multicolumn{1}{c}{ Tugas Peserta } \\
\hline Pemberian Materi & Memperhatikan paparan Materi \\
- matematika AUD (kurikulum, media, dll) & \\
- Rancangan Pembelajaran & \\
- Learning trajectories based Inquiry & Peserta mememperhatikan dengan seksama \\
\hline $\begin{array}{l}\text { Penayangan video dengan judul Sulit } \\
\text { mengenal konsep bilangan }\end{array}$ &
\end{tabular}

\section{Kerja Mandiri}

(peserta dibagi per kelompok sebanyak tiga orang)

Menerapkan model

Learning Trajectories Based Inquiry

\section{Kerja Mandiri \\ (peserta dibagi per kelompok sebanyak tiga orang) \\ Menerapkan model \\ Learning Trajectories Based Inquiry}

Membuat lesson plan

Presentasi per kelompok
Merumuskan masalah penelitian berdasarkan Video yang disajikan Mengajukan hipotesis terhadap masalah yang telah dirumuskannya
Melakukan pengamatan dikelas dan mencari referensi terkait dengan masalah yang dihadapi

Menganalisis data yang sudah didapat untuk mendapatkan suatu konsep

Mengambil kesimpulan berdasarkan data dan menemukan sendiri pemecahan membuat lesson plan dengan learning trajectories based inquiry

- Peserta mempresentasikan hasil penemuan dan lesson plan yang telah dibuat

- Jika ada masukan, memperbaiki kembali lesson plan

Penerapan di sekolah
Menerapkan lesson plan di sekolah masingmasing 
Pada pengembangan program ini terdapat tahapan yang akan dikembangkan diataranya

1. Penayangan video pembelajaran. Peserta akan mendapatkan pertanyaan berkaitan dengan video tersebut. Kegiatan ini ditujukan untuk mengetahui kemampuan awal peserta

2. Pemberian Materi diataranya Matematika AUD, kurikulum, media, dan Lesson plan.

3. Diskusi Kelompok. Kegiatan tersebut merupakan tahapan dari inqury. Diantaranya merumuskan masalah di kelas dan identifikasi respon siswa di kelas, mencari referensi antisipasi masalah, mengidentifikasikan antisipasi masalah berdasarkan pengalaman dan referensi, mengajukan hipotesis, menganalisis data mengambil kesimpulan, membuat Lesson plan

4. Penerapan di sekolah. Menerapkan Lesson plan di sekolah masing-masing

5. Refleksi. Melakukan refleksi dari hasil penerapan Lesson plan dan memperbaiki Lesson plan yang sudah dibuat hasil dari refleksi

Dari kegiatan PDP tersebut, akan terlihat learning trajctories peserta terutama pada saat analisis artikel dan diskusi kelompok.

\section{LEARNING TRAJECTORIES BASED INQUIRY MEMBANGUN MATHEMATICAL KNOWLEDGE FOR TEACHING}

Mathematics Knowledge for Teaching (MKT) dapat dibangun dengan learning trajectories (LTs). Wilson (2012) menemukan LTs pada pembelajaran guru mendukung penyempurnaan dari MKT. Secara khusus, wilson menghubungkan antara PCK dan SMK guru dan partisipasi mereka dalam diskusi tentang tugas-tugas belajar profesional yang dirancang untuk mengajarkan mereka tentang satu LTs. (Wilson, 2013).

Dari sudut pandang LTs, menganggap domain PCK berhubungan dengan pengetahuan yang muncul dari sebuah fokus pada perkembangan kognitif peserta didik. Hal tersebut muncul karena pemahaman guru mengenai logika peserta didik. Ball (2008) menegaskan pendidik harus mengantisipasi apa yang biasanya dipikirkan peserta dan apa yang membingungkan bagi mereka. Ketika memilih sebuah contoh, pendidik perlu memprediksi apa yang akan dianggap menarik dan memotivasi oleh peserta didik. Ketika 
memberikan tugas, pendidik perlu mengantisipasi apa yang peserta didik lakukan terhadap tugasnya dan apakah mereka akan menganggapnya mudah atau sulit.

Domain SMK mewakili aspek pengetahuan pendidik yang berpusat pada logika disiplin ilmu. Dalam membangun learning trajectory, pendidik harus mempunyai konsep teori atau referensi teori belajar. Mustahil bagi seorang pendidik mampu membangun learning trajectori tanpa memahami teori belajar.

Pengetahuan tentang LTs membantu pendidik baik dalam menempatkan lokasi dalam jalur pembelajaran dan mengembangan hipotesis yang spesifik tentang jenis bantuan untuk membantu siswa dalam mecapai tujuan (Supovitz,2013 ).

Berkenaan dengan hal tersebut, berikut ini adalah aspek-aspek yang akan diukur dengan pada pelaksanaan PDP dengan model LTBI

Tabel 3. Aspek Pengukuran MKT

PDP dengan LTBI

1. Merumuskan masalah penelitian berdasarkan Video yang disajikan

2. Mengajukan hipotesis terhadap masalah yang telah dirumuskannya

3. Melakukan pengamatan dikelas dan mencari referensi terkait dengan masalah yang dihadapi

4. Menganalisis data yang sudah didapat untuk mendapatkan suatu konsep

5. Mengambil kesimpulan berdasarkan data dan menemukan sendiri pemecahan

6. Membuat lesson plan dengan learing trajectories based inquiry

Aspek yang diukur

Subject Matter Knowledge (SMK) Pedagodical Content Knowledge (PCK)

\section{Common}

content

knowledge (CCK)

1. Pengetahuan tentang matematika yang diajarkan, termasuk istilah matematika dan notasi

2. Pengetahuan dan keterampilan matematis yang digunakan dalam situasi selain mengajar

3. Bagaimana memecahkan soal matematika dengan benar akan dipandang sebagai pengetahuan konten umum

4. Mengenali kekurangan pemikiran siswa ketika anakanak menyajikan solusi yang salah

Specialized

Content knowledge (SCK)

1. Pengetahuan tentang matematika khusus untuk pengajaran;

2. Pengetahuan matematika di balik kesalahan siswa dan pendekatan yang tidak standar;

3. Pengetahuan dan kemampuan spesifik yang terbentuk ketika mengajar

\section{Knowledge of}

content and students (KCS)

1. Siswa dalam kaitannya dengan matematika

2. Apa yang biasanya ditemukan oleh siswa

3. Konsepsi dan miskonseppsi umum pada siswa tentang konten tertentu dalam matematika

4. Antisipasi respon dan kesalahfahaman siswa

Knowledge of content and teaching (KCT)

1. Desain instruksi termasuk konten

2. Representasi dan model yang berguna,

3. Tugas instruksional

4. Pemahaman matematika yang spesifik dan sebuah pemahaman isu pedagogis yang mempengaruhi pemebelajaran siswa

5. Membangun pengetahuan utama siswa

6. Memahami urutan masalah

7. Mengevaluasi bagaimana menunjukkan ide-ide matematika dalam cara-cara 
yang berbeda untuk membantu siswa mencapai penguasaan konsep yang spesifik

Knowledge of content and curriculum

1. Pengetahuan konten dan kurikulum.

2. Gagasan tentang pengetahuan kurikuler

\section{KESIMPULAN}

Dalam penelitian ini dilakukan Profesional Development Program (PDP) dengan Learning Trajectories Based Inquiry (LTBI). LTBI merupakan lintasan belajar dengan menekankan kepada proses mencari dan menemukan. Dalam hal ini, pengetahuan dibangun melalui proses pencarian, serta proses berpikir kritis dan analitis untuk merumuskan kesimpulan. Dalam perancangannya Program profesional developmen dengan LTBI dilakukan dengan 6 sesi dengan beberapa fase diantaranya mengajukan hipotesis terhadap masalah yang telah dirumuskannya, melakukan pengamatan dikelas dan mencari referensi terkait dengan masalah yang dihadapi, menganalisis data yang sudah didapat untuk mendapatkan suatu konsep, mengambil kesimpulan berdasarkan data dan menemukan sendiri pemecahan. Target dari program ini adalah guru dapat membuat lesson plan yang dapat digunakan untuk kegiatan pengembangan matematika di kelas.

\section{REFERENSI}

Blaiklock, Ken.2012. Te Wha riki, the New Zealand early childhood curriculum: is it effective?. International Journal of Early Years Education Vol. 18, No. 3, September 2010, 201_212

Ball, D. L., \& Bass, H. (2003). Toward a practice-based theory of mathematical knowledge for teaching. In B. Davis \& E. Simmt (Eds.), Proceedings of the 2002 Annual Meeting of National Council of Teachers of Mathematics. (2016).executive summary Principles and Standards for School Mathematics. Availabe at http://www.nctm.org/standards/

Baroody, A. J. (2009). Fostering early numeracy in preschool and kindergarten. Encyclopedia of language and literacy development (pp. 1-9). London, ON: Canadian Language and Literacy Research Network. 
Baroody, A. J. 2010. Fostering Early Numeracy in Preschool and Kindergarten. Available at http://www.child-encyclopedia.com/numeracy/according-experts/fostering-earlynumeracy-preschool-and-kindergarten. Accessed 11 November 2016

Clements, D. H. (2001). Mathematics in the preschool. Teaching Children Mathematics, 7(4), 270-275.

Clements, D.H., Sarama, J. and DiBiase, A.M. eds., 2003. Engaging young children in mathematics: Standards for early childhood mathematics education. Routledge

Clements, D. H., \& Conference Working Group. (2004). Part 1: Major themes and recommendations. In D. H. Clements, J. Sarama, \& A.-M. DiBiase (Eds.), Engaging young children in Mathematics: Standards for early childhood mathematics education, pp. 7-76. Mahwah, NJ: Lawrence Erlbaum.

Clements, Douglas H and Sarama, Julie. 2009. Learning Trajectories in Early Mathematics - Sequences of Acquisition and Teaching. Tersedia: http://literacyencyclopedia.ca/index.php?fa=items.show\&topi $\mathrm{cId}=270$.

Cohrssen, Caroline, et. all. 2016. Articulating a rights-based argument for mathematics teaching and learning in early childhood education. Australasian Journal of Early Childhood. Volume 41 Number 3 September 2016

Cullen, J. (2000). The early years conceptual issues and future challenges. New Zealand Research in Early Childhood Education, 3, 3-11.

Duncan, G., Dowsett, C., Claessens, A., Magnuson, K., Huston, A., Klebanov, P., et al. (2007). School readiness and later achievement. Developmental Psychology, 43(6), $1428-1446$.

Gardner, Howard. "Frames of Mind: The Theory of Multiple Intelligences." (1984).

Gallenstein, Nancy L. 2005. Engaging Young Children in Science and Mathematics .Journal of Elementary Science Education, Vol. 17, No. 2 (Fall 2005), pp. 27-41.

Gelman, R., \& Meck, E. (1983). Preschoolers' counting: Principles before skill. Cognition, $13,343-359$.

Hill, Heather, at.all. Learning Mathematics for Teaching: Results from California's Mathematics Professional Development Institutes. Journal of Research on Mathematics Education. Vol 35. No 5 , 330-351

Kühne, et.all. 2013. A learning pathway for whole numbers that informs mathematics teaching in the early years. South African Journal of Childhood Education | 2013 3(2): 77-95 | ISSN: 2223-7674 |C UJ

Lee, J., \& Ginsburg, H. (2007). Preschool teacher's beliefs about appropriate early literacy and mathematics education for low- and middle-socioeconomic status children. Early Childhood Education Journal, 18(1), 111-143.

Linder, et, all. 2011. Mathematics in Early Childhood: Research-Based Rationale and Practical Strategies. Early Childhood Educ J (2011) 39:29-37

Lino, dalila. 2010. EARLY CHILDHOOD EDUCATION: KEY COMPETENCES IN TEACHER EDUCATION. Journal Plus Education . available at http://uav.ro/jour/index.php/jpe/article/view/668

Leong, Eu, Kwan, et. all. 2015. Understanding Malaysian Pre-Service Teachers Mathematical Content Knowledge and Pedagogical Content Knowledge. Eurasia Journal of Mathematics, Science \& Technology Education, 2015, 11(2), 363-370

NCTM. 2013. Mathematics in Early Childhood Learning . A Position of the National Council of Teachers of Mathematics

Watts, et.all. What's Past Is Prologue: Relations Between Early Mathematics Knowledge and High School Achievement. EDUCATIONAL RESEARCHER. October 2014 vol. 43 no. 7 352-360 
Wilson, P. H., Sztajn, P., \& Edgington, C. (2013). Designing professional learning tasks for mathematics Learning Trajectories. PNA, 7(4), 135-143.

Wilson, et. All. 2014. Teachers' use of their mathematical knowledge for teaching in learning a mathematics learning trajectory. J Math Teacher Educ (2014) 17:149-175 